\title{
Healing in survivors of torture
}

\author{
Athar Yawar BM MSc
}

J R Soc Med 2004;97:366-370

A man fought with the Devil. After a titanic struggle, he grabbed the Devil's beard in his hand and gave it a mighty yank.

He woke up. The beard in his hand was his own. ${ }^{1}$

Torture has been widely construed as medieval; however, it never went away and is increasingly being recognized as a problem of our time. The following typology, though imperfect, may help to describe the forms torture takes.

\section{THE STRUCTURE OF TORTURE}

\section{Torture as reform}

'We are different from the persecutors of the past. . .

We do not destroy the heretic because he resists us; so long as he resists us we never destroy him. We convert him, we capture his inner mind, we reshape him. We burn all evil and all illusion out of him; we bring him over to our side, not in appearance, but genuinely, heart and soul. We make him one of ourselves before we kill him'. ${ }^{2}$

Particularly where it is associated with the more prosperous countries, or those that see themselves as bringers of civilization, torture may wear a humane, almost kindly face. It goes under euphemisms such as 'pressure', 'shock', 'stress' and 'duress'; and the perpetrators themselves will see a distinction between what they do and what they consider to be torture. ${ }^{3}$ However, this is as vicious a form of torture as any: it can leave people mentally and physically disabled - indeed, the practitioners acknowledge the potential to render people psychotic, in hours or days. ${ }^{4}$

The victim is typically subjected to physical punishments that do not leave obvious scars, and this means that, should the case ever come under legal scrutiny, physical evidence of torture may be lacking. However, many ways of causing extreme pain remain possible. The subject will be tightly handcuffed and restrained, often in a way that damages nerves and muscles; he may be suspended in painful postures, or forced to assume them himself, with damage to muscles and joints; he may be subjected to electric shocks. Typically, he will be kept in a small, dark, bedless cell, with

Medical Foundation for the Care of Victims of Torture, 111 Isledon Road London N7 7JW, UK

E-mail: atharyawar@doctors.org.uk inadequate food and variable toilet facilities, so that his own filth stains the floor and dampens his clothes. He may be exposed to extreme heat or cold, and perhaps forced to stare at the sun. Beatings with rifle butts and kicking with military boots can cause lasting damage; lashing on the soles of the feet can make walking painful for years. A doctor may well be present, persuading the prisoner that he is in the wrong and that all he must do is recant. The doctor may even provide medication — as a symbol of civilization, or to keep the patient alive (deaths in custody can be inconvenient), or to cause pain or disability. 5,6

Techniques of psychological torture may assume prominence. ${ }^{7}$ They include the following.

\section{Disorientation}

The subject may be hooded or blindfolded. He will be kept without a clock or calendar in a dark cell, and deprived of sleep for days and nights on end. He may be exposed to loud noises or music beyond his endurance. He will be isolated from his fellow prisoners, at least temporarily. He may not be told where he is, even to the nearest continent. If interrogated, he may well be entirely ignorant of the subject - not even knowing what his torturers want to know, or what are the grounds for release. He will be out of contact with his family, who may be dead or alive or even in the next cell.

\section{Degradation}

Sexual torture seldom leaves scars. Enforced nakedness and sexual assaults such as the tying of weights to testicles are also common. Victims are insulted, harangued, and physically humiliated with filth and random beatings.

\section{Debilitation}

The most powerful instrument is fear, which lurks in torture complexes like a physical presence. The conditions of detention reduce the detainee's mental and physical resilience. Screams and threats are heard into the night, and inmates may be exposed to videos urging them to mend their ways. The subjects may be offered crude inducements to comply with the torturers.

\section{Torture as punishment}

'Torture is the inversion of the trial, a reversal of cause and effect. The slogans of the South Vietnamese 
torturers announce what is there and elsewhere always visible . . . "If you are not a Vietcong, we will beat you until you admit you are; and if you admit you are, we will beat you until you no longer dare to be one",'6

Here, the torturers see themselves in the image of judge and avenger, meting out punishment to rebels and reprobates or those who have dared stand in their way. Frank sadism is common here, as people are beaten to death, burned, crushed, and kept in wretched conditionsfor example, naked, several to a cell, with an open latrine in the centre. This model may be adopted partly for economic reasons, since it is cheaper to run than the first type, requiring less training, time and physical space. It is common in the poorer countries of the world.

\section{Torture as conquest}

'[The native Tasmanians] had been used for slave labour and sexual pleasure, tortured and mutilated. They had been hunted like vermin and their skin had been sold for government bounty. When the males were killed female survivors were turned loose with the heads of their husbands tied around their necks. Males who were not killed were usually castrated. Children were clubbed to death. When the last indigenous Tasmanian male, William Lance, died in 1869, his grave was opened by a Member of the Royal Society of Tasmania, Dr George Stokell, who made a tobacco pouch from his skin.' 8

This is the model for ethnic cleansing, when populations are evicted and brutalized. It requires the fiction that there are no civilians, so that women and children are enemy combatants, or possessions and playthings. The mobilization of one population, or part of a population, against another means that almost anyone can become a torturer-as in Sierra Leone, where the fluctuating dominance of militias was marked by the casual drugged sadism of the child soldier. ${ }^{9}$

So far, I have referred to the victim of torture as 'he', but experience at the Medical Foundation indicates that abuse of women is increasing: whereas a few years ago the proportion of female patients was $25 \%$, it is now closer to $40 \%$. A remarkable account of the torture of women in Latin America was provided by Marjorie Agosin. ${ }^{10}$

\section{THE REASONING OF TORTURE}

How can people do this to one another? In society, few people are actively sadistic or psychopathic. To impose one's will on another, particularly with brutality, is possible only if one views oneself as wiser or more valuable; and this notion is fostered by creeds that exalt certain groups and denigrate others. People torture in the name of ideals that, in their culture, would be held to be unassailabledemocracy, freedom, Islam. What counts is the label, not the reality of these doctrines. Milgram demonstrated the power of labels when, in his experiment, men in white coats persuaded volunteers to deliver what they thought were lethal electric shocks to screaming individuals (who were acting the part). The quiet priestly authority of 'progress' outweighed the volunteers' own consciences. ${ }^{11}$

Correspondingly, the victim is casually seen as subhuman. Common metaphors are those of vermin and disease: women and children have been described as lice, cockroaches, cancers. ${ }^{12}$ A female torturer who recently came to public attention was said by someone from her home town to have come from a background where 'Tormenting Iraqis . . . would be no different from shooting a turkey' (Daily Mirror 7 May 2004). Although it is a statistical certainty that some of those tortured will be innocent, this is not seen as important. ${ }^{13}$ Torturers may even excuse themselves on the grounds that their method of torture is more humane than the locals' system of justice.

One variety of the allegedly subhuman is the 'inhumanly dangerous' - the implacable Other, bent on destroying Us. Torture has gained a certain respectability in some circles on the notion of the 'ticking bomb'; in other words, when an immense crime is imminent, people may legitimately be tortured to find out about it. But this theory rests on the following assumptions (among others):

- That it can be reliably known when a dangerous event is imminent: recent history indicates that this is not so

- That people with relevant information can be reliably identified: this too has not been the case

- That torture is a reliable method of gathering information: it is not

- That any information elicited can be acted upon decisively: this is debatable

- That someone innocent of a crime is a legitimate subject for torture: the suspect, by definition, is innocent since the crime has not yet been committed

- That people will not seek to avenge torture

- That, under similar circumstances, those who advocate the theory would be happy to be tortured.

Human beings, regrettably, are easily conditioned to the notion that other sorts of people are different, inferior, intrinsically dangerous. Education is no protection against such conditioning - indeed, the leaders and propagators of political violence are commonly from among the well educated. But an intrinsic feeling of superiority, or necessity, is not enough: the torturer must be placed in an appropriate role. Zimbardo demonstrated the importance of this when he placed students in a mock jail, some as prisoners, others as guards. Within a few days the 
experiment had to be stopped, such was the treatment meted out to the prisoners by the guards. ${ }^{14}$ The torturer may see himself as a defender of humanity, when all the while his conduct is dominated by brutality and corruption. In areas where torture is well established, people are swept up off the streets on a suspicion or a word; bribery secures release, and maladministration results in detention or even execution of the innocent. ${ }^{5}$

Torture may be perceived as the putting of a 'question' to determine 'truth'; but the answers obtained are often highly misleading. ${ }^{15}$ Commonly, however, the aim of torture is not to question but to answer - to debilitate, condemn, and spread crippling fear. ${ }^{16}$ Confessions can lurch from the unlikely to the absurd, ${ }^{17}$ and the torturer's empathy is often so dulled that he cannot tell the difference. Torture never serves justice.

\section{HEALING IN SURVIVORS OF TORTURE}

Doctors are often encouraged to consider their work as applied physiology. If they do so with survivors of torture, they will fail. The needs of those individuals can be crudely represented by the diagram in Figure 1.

Wherever they are, survivors of torture are in exile. They are in exile from themselves: the once sharp mind may have been dulled by fear and exhaustion, to say nothing of the brain damage caused by repeated beatings (the incidence of epilepsy in survivors of torture is remarkably high). The person who once bestrode his world may be physically weak, disabled, in constant pain. Every twinge and ache may bring back memories of torture - a reminder that the torturers are still winning.

Culturally, the survivor of torture is often deeply bereaved. ${ }^{18}$ 'Home' now may be a squalid, lonely room in a dangerous part of town in a new country. The basic requirements of home - companionship and safety - are not fulfilled. The survivor of torture is in a strange land whose spiritual geography he does not recognize. Moreover, the experiences of torture may have caused him to question his most basic assumptions - who is he, who is God? The threat of deportation, and resumed torture, may loom closer as

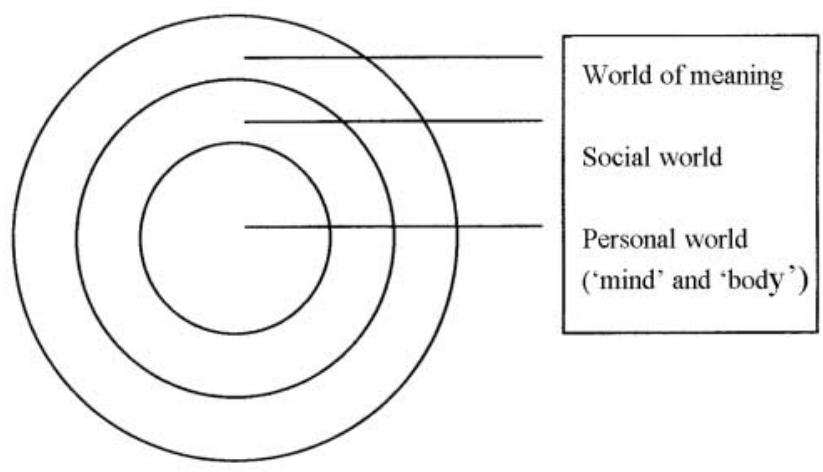

Figure 1 The different worlds of a torture survivor the months pass. Even were the survivor, by good fortune, able to return to his country in safety, home would not be the same again. Torture isolates people by their experience, their disability and the stigma of fear. And the homeland also changes. Inhabitants of the Bosnian market town of Sanski Most told how, for years after the carnage there, the river every so often would reveal its cargo of bones.

In my own efforts at being a doctor to survivors of torture, my first priority, usually unspoken, has been to give them a 'home'. No matter where they are and what they experience in the rest of their lives, the consulting room should be a place where they can find companionship and safety, and be and find themselves. Characteristically, survivors of torture have lost the ability to think with clarity and to trust; unless the person is able to relax and to open up, the basic medical and psychological history will never fully emerge.

The first act for the doctor has less to do with treatment than with witnessing. In the UK, survivors of torture must present formal argument in order to be granted 'leave to remain'. Usually this will include evidence that they have been tortured. As noted earlier, physical scars are often absent, though thorough examination for soft-tissue damage, epilepsy and psychiatric debility, among other things, may well be revealing. Helpful guidelines exist. ${ }^{19-21}$ It is often reported that 'bogus asylum seekers' report torture where none has happened; what tends to go unremarked is that those who have been tortured often underreport it. Over time, a good rapport allows the unveiling of scars, physical and mental — the cigarette burn, the rape. It does not help that many immigration lawyers lack skill and attentiveness and time, and that the most damaged patients may be precisely those whose story varies the most. This should not be new to doctors: as Longmore points out in cardiology, the sounds remain the same but the patient's story changes every time. ${ }^{22}$ But still the idea persists that a genuine story of torture is necessarily filled with accurate chronological detail. It should be borne in mind that patients with post-traumatic stress disorder (PTSD), depression, temporal lobe epilepsy, and certain kinds of brain damage are likely to have memory impairment. ${ }^{23}$ The simple sleep deficit endemic to survivors of torture can play havoc with the mind. ${ }^{23}$ Clearly, a responsible doctor must be on the lookout for inconsistencies and implausibilities; but a few exaggerations by a desperate man do not constitute a tissue of lies, and a strange story may be the result of different perspectives. Time is often the great diagnostician, as false stories sound ever falser and true stories fall into place. Most importantly the doctor is not required to be judge and jury; his task is to record the evidence as impartially as possible and act accordingly. If communicating with a court, he should try to use language the court will understand-appropriate 
terminology, close reasoning and even numbered paragraphs.

It is often said that, until the patient has been awarded 'leave to remain', effective psychotherapy is impossible, but in my experience this is not so. Psychotherapy may be crucial at this stage, to allow the patient to cope with his legal and social predicament. As well as compassion and subtlety, it demands practical attention to the social situation: a patient with a social circle, accommodation and even meagre benefits is in the best position to make progress. The doctor's role is to help the patient regain strength until no longer needed.

The position of the survivor of torture thus transcends simple diagnosis. Nonetheless, doctors do speak in the language of diagnoses, and the categories of PTSD and depression can often be used to describe the realities that unfold in the consulting room, however inadequately.

It has been argued that survivors of torture are not unwell but responding normatively to an absurd situation; that PTSD as a diagnosis is the result of cultural manufacture; and that, in their home countries, these people would not consult a doctor. ${ }^{24}$ This seems plausible until one considers that exactly the same could be said of depression, unquestionably a serious illness. Littlewood has pointed out that the idea of mood being 'depressed' or 'elevated' dates from the mid-18th century, when linear scales became dominant in science; it is still an alien idea in many parts of the world. ${ }^{25}$ Littlewood has proposed an elegant way to consider the cultural contribution to illness (Figure 2).

It may therefore be seen that PTSD, like depression, is in part based on universals and in part based on cultural constructs. That there is a universal component is not in doubt: elephant calves, for instance, have been reported to wake up screaming after their mothers have been killed. But patients who are survivors of torture may not initially show their suffering as distress, just as those who have experienced profound loss need not present with depression; and distress may be framed in ways other than the psychological, and vastly different from PTSD. Survivors of the Rwandan genocide, in Rwanda, rarely used the idioms of PTSD to frame their distress. ${ }^{24}$ Categories have their limits, particularly in cross-cultural work.

Where therapist and patient do not share a language the role of the interpreter is crucial, not just linguistically but also on a cultural level. The best interpreters, with an awareness of social structures and subtleties, are invaluable allies in treatment.

\section{UNEXPECTED CONSEQUENCES OF TORTURE}

Survivors of torture may, over time, grow and flourish. Those selected for torture tend to be the young and fit, the articulate and energetic. As is the lot of first-generation immigrants, they may initially take on menial work, but they and their descendants are likely to enrich their adopted society.

Although psychological debility commonly flows from the experience of torture, ${ }^{26-28}$ the stripping away of habit and security sometimes leads to a gain in wisdom and compassion. ${ }^{29}$ Contrast this with those who inflict or condone torture. It should not be forgotten that the diagnosis of PTSD was initially developed around the narratives not of those who had undergone torture but of those who had inflicted it - Vietnam veterans haunted by their experiences and memories. Linda Grant has documented how those who oppress civilians carry the

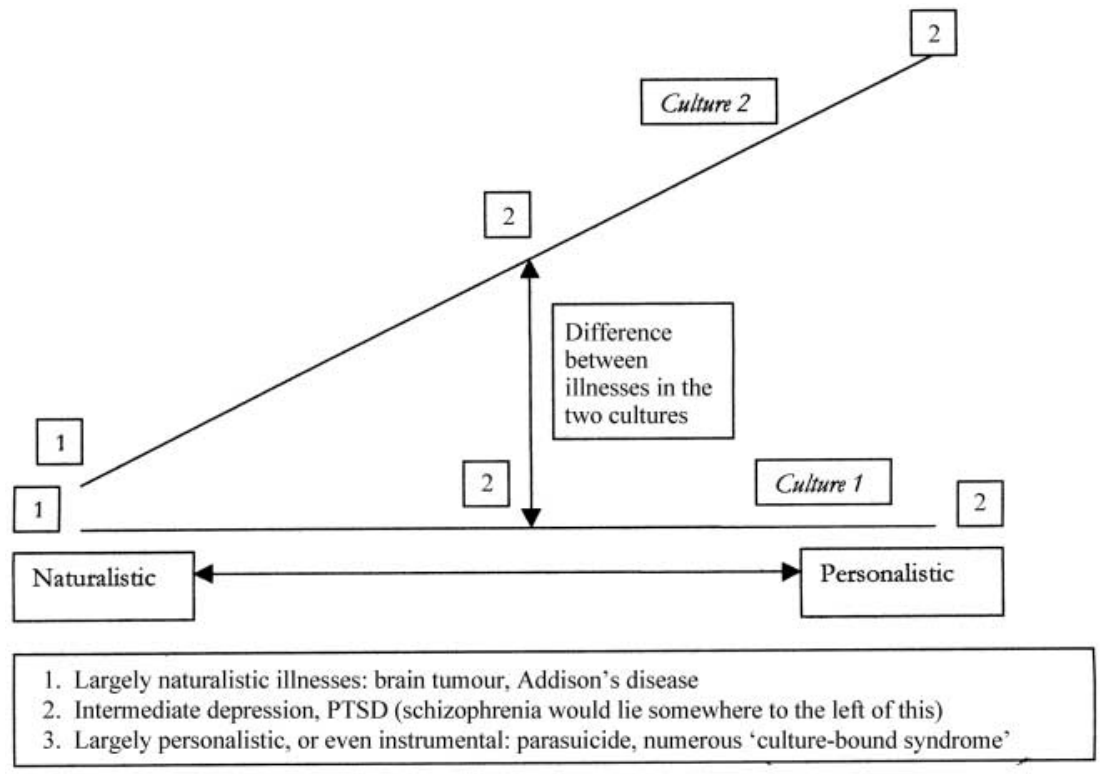

Figure 2 The cultural contribution to illness (after Littlewood) 
cruelty into their everyday lives, damaging themselves and those around them. ${ }^{32}$ Inhumanity cannot be inflicted without being internalized. As Ariel Dorfman commented:

'Torture does not... only corrupt those directly involved in the terrible contact between the two bodies . . . Torture also corrupts the whole social fabric because it prescribes a silence of what has been happening between those two bodies; it forces people to make believe that nothing, in fact, has been happening; it necessitates that we lie to ourselves about what is being done not that far, after all, from where we talk, while we munch chocolate, smile at a lover, read a book, listen to a concerto, exercise in the morning. Torture obliges us to be deaf and blind and mute . . . [to] close [our] eyes and ears and hearts.' ${ }^{13}$

Any society that practises torture renders itself inherently unstable, although it may be propped up for a while by wealth. An accumulation of small cruelties leads to decay; moreover, those labelled as the Other become the Other, neither engaging with society nor sympathetic to it. As individual doctors we tend to shy away from involvement in the great sweep of history; but, to the extent that we can be human, we can both limit the damage caused by torture and even atone for it.

Acknowledgments I thank Helen Bamber and Roland Littlewood for instruction and inspiration. I also thank my interpreters and in particular Gulalai Baqi, for her excellent unpaid work during my research.

\section{REFERENCES}

1 Shah I. The World of Nasrudin. London: Octagon Press, 2003

2 Orwell G. Nineteen Eighty-Four. Harmondsworth: Penguin, 1983

3 Danner M. Torture and truth. NY Rev Books 2004;51(1):46-50

4 Leigh D. UK forces taught torture methods. Guardian 8 May 2004

5 Rejali D. Torture and Modernity. Oxford: Westview Press, 1994

6 Scarry E. The Body in Pain. Oxford: Oxford University Press, 1985

7 Danner M. The logic of torture. NY Rev Books 2004;51(11):70-4

8 Gray J. Straw Dogs. London: Granta, 2002
9 Human Rights Watch. Sierra Leone: Getting Away with Murder, Mutilation, and Rape. New York: HRW, 1999

10 Agosin M, ed. Surviving Beyond Fear. New York: White Pine, 1993

11 Milgram S. Obedience to Authority: An Experimental View. New York: Harper Collins, 1982

12 Sontag S. Illness as Metaphor: AIDS and its Metaphors. Harmondsworth: Penguin, 1991

13 Dorfman A. Are there times when we have to accept torture? Guardian 8 May 2004

14 www.prisonexp.org

15 Alleg H (transl. J Calder). The Question. London: John Calder, 1958

16 Ackroyd C, Margolis K, Rosenhead J, et al. The Technology of Political Control, 2nd edn. London: Pluto, 1980:229-46

17 Rose D. How we survived jail hell. Observer 14 March 2004

18 Eisenbruch M. From post traumatic stress disorder to cultural bereavement: diagnosis of Southeast Asian refugees. Soc Sci Med 1991;33:673-80

19 Medical Foundation for the Care of Victims of Torture. Guidelines for the Examination of Survivors of Torture, 2nd edn. London: MFCVT, 2000

20 Rasmussen OV. Medical aspects of torture. Dan Med Bull 1990;37(suppl 1):1-88

21 Iacopino V, Peel M. The Medical Documentation of Torture. London: Greenwich Medical Media, 2002

22 Longmore M, Wilkinson I, Török E. Oxford Handbook of Clinical Medicine 5th edn. Oxford: Oxford University Press, 2001:39

23 Cohen J. Errors of recall and credibility: can omissions and discrepancies in successive statements reasonably be said to undermine credibility of testimony? Medico Legal J 2001;69:25-34

24 Summerfield D. A critique of seven assumptions behind psychological trauma programmes in war-affected areas. Soc Sci Med 1999;48:1449 62

25 Littlewood R. The Butterfly and the Serpent. London: Free Association, 1994:166-70

26 Başoğlu M, Paker M, Paker Ö, et al. Psychological effects of torture: a comparison of tortured with nontortured political activists in Turkey. Am J Psychiatr 1994;151:76-81

27 Holtz TH. Refugee trauma versus torture trauma: a retrospective controlled cohort study of Tibetan refugees. J Nerv Ment Dis 1998; 186:24-34

28 Mollica RF, McInnes K, Pham T, et al. The dose-effect relationships between torture and psychiatric symptoms in Vietnamese ex-political detainees and a comparison group. J Nerv Ment Dis 1998;186:543-53

29 Frankl V (transl. I Lasch). Man's Search for Meaning. London: Hodder \& Stoughton, 1987

30 Young A. The Harmony of Illusions. New Jersey: Princeton University Press, 1995

31 Haley S. When the patient reports atrocities. Arch Gen Psychiatry 1974;30:191-6

32 Grant L. Green line, red line? Jewish Chronicle, 12 March 2004 